\title{
Diversity of phenotypic characteristics of White Tailed-Yellow Chicken populations reared under free range system in Phitsanulok Province, Thailand
}

\author{
SUPHAWADEE YAEMKONG ${ }^{1, \boldsymbol{\varphi}}$, NGUYEN NGOC TUAN ${ }^{1,2, w}$ \\ ${ }^{1}$ Program of Animal Science, Faculty of Food and Agriculture Technology, Pibulsongkram Rajabhat University. 156, Plai Chumphon Subdistrict, \\ Mueang District, Phitsanulok, Thailand, 65000. Tel./fax.+66-055-267080, `email: suphayaku@ hotmail.com. \\ ${ }^{2}$ Faculty of Fisheries, Vietnam National University of Agriculture, Gia Lam, Ha Noi, Viet Nam."email: nntuan245@gmail.com.
}

Manuscript received: 26 February 2019. Revision accepted: 19 April 2019.

\begin{abstract}
Yaemkong S, Tuan NN. 2019. Diversity of phenotypic characteristics of White Tailed-Yellow Chicken populations reared under free-range system in Phitsanulok Province, Thailand. Biodiversitas 20: 1271-1280. The objective of this study was to evaluate phenotypic diversity of White tail-yellow chickens in Mueang District, Phitsanulok, Thailand. A total of 209 male chickens from the purposive samples were collected, and then analyzed by using descriptive statistics, correlation and least squares mean for subclasses of each factor. The results showed that the phenotypic of White tail-yellow Chickens had the highest white-yellow beak (60.29\%), hin comb (65.50\%), golden-yellow neck plumage (95.69\%), back plumage (96.17\%) and wing plumage (67.94\%), white-black long curving tails $(70.11 \%)$, black back tails $(71.14 \%)$ and white-yellow shank $(59.81 \%)$ for qualitative traits. The quantitative traits such as body weight, body height, body length, body width, wing length, shank length, and toes length were $2.78 \pm 0.58 \mathrm{~kg}, 61.95 \pm 3.77 \mathrm{~cm}$, $24.93 \pm 1.66 \mathrm{~cm}, 16.62 \pm 1.91 \mathrm{~cm}, 41.85 \pm 2.52 \mathrm{~cm}, 12.72 \pm 0.77 \mathrm{~cm}$, and $8.39 \pm 0.66 \mathrm{~cm}$, respectively. The highest positive correlation was recorded between neck plumage and back plumage $(\mathrm{r}=0.70 ; \mathrm{p}<0.01)$. Moreover, body weight was the highest correlation with wing length $(0.58 ; \mathrm{p}<0.01)$ whereas body length was the highest positive correlation with wing plumage $(0.21 ; \mathrm{p}<0.01)$. However, beak and comb had no significant effect on all traits $(p>0.05)$ except for neck, back and wing plumage, long curving tail, back tail and shank color $(\mathrm{p}<0.05)$.
\end{abstract}

Keywords: Phenotypic, Phitsanulok, Thailand, White tail-yellow Chicken

\section{INTRODUCTION}

Thai native chicken is an important part of traditional rural living of Thai farmers. There are promoted as a chicken genetic resource for the purpose of conservation breeding and sustainable utilization of the chickens. Thai native chicken breeds are becoming an increasingly important food source to those who live in rural areas in Thailand (Choprakarn and Wongpichet 2007; Mekchay et al. 2014; Laenoi et al. 2015; Yaemkong et al. 2017). However, the native chicken populations in Thailand was mostly non-descript with wide variation in size, shapes and plumage colors (Amnueysit et al. 2000a; 2000b; Yaemkong 2014; Maw et al. 2015; Buranawit et al. 2016). They have a rich genetic diversity of native chickens and vary in appearance according to the locality in which they have been bred. One of them, namely White Tailed-Yellow Chicken (WTYC) or Lueng Hong Khao Chicken is native chicken in Phitsanulok Province and it is generally interesting widespread for conservation and development of White-tailed yellow chicken which is unique breed and special characteristics in country. The breeds of which have been preserved and continuously developed. This bird has recently become a signature of the province. The chicken's beauty and the awesome uniqueness are the main reasons for the people to have the desires to obtain these chickens. Moreover, these birds are also dominant in state fighting as they are called "King Narasuan's fighting chicken". According to the Thai history, King Narasuan, one of the most famous Thai kings, once resided in Hong Sa Wadee, a big city in Burma, brought along with him a good fine fighting chick to compete against that of the Burmese king. The winning result of King Narasuan's chick became the start of the history of this very fine Thai fighting bird. The chick is sometimes called a white-tailed yellow chicken or King Narasuan's fighting chicken or a high classed chicken. This bird both looks handsome and acquires special features such as walking smartly like a king and roaring loudly like a big lion, which is so pleasant to hear (Tungtakanpoung 2015). Nowadays, there are so many different factors affecting this special chicken resulting to their present changing of quantitative and qualitative traits leading to several slowly-developed undesired and more diversity of phenotypic characteristics (Duangjinda et al. 2012; Yaemkong 2014). One major disaster on this special chicken was the coming of the bird flu, which led to the enormous elimination of the chicken. As a result, so many good developments of this special breed have been put to a haul as well as the stop of the breed developing continuity. At present, the worsening situations of the chick's breed developments are in term of a worrying one. However, we really need to put a huge effort to preserve this very special bird's fighting breed. Therefore, the objective of this study was to characterize diversity of phenotypic characteristics 
of WTYC populations reared under free-range system in Phitsanulok Province, Thailand.

\section{MATERIALS AND METHODS}

\section{Study area}

The study was conducted at Mueang District, Phitsanulok Province, historic city in lower northern part of Thailand (16 $46^{\prime} 20.99^{\prime \prime}$ North latitude and $100^{\circ} 49^{\prime} 20.99^{\prime \prime}$ East longitude). This area is proximate of 851,357 people and covers 10,815 square kilometers, or $6.4 \%$ of area in the north of Thailand and $2.1 \%$ of area in Thailand (Figure 1). Topography of Phitsanulok lies primarily on flat land with some hills. The eastern portion of the district has some wooded area. Phitsanulok has a tropical savanna climate. The weather in this area generally has approximately $27.8^{\circ} \mathrm{C}$ for average daily temperature, $33.4^{\circ} \mathrm{C}$ for high temperature, $23.1^{\circ} \mathrm{C}$ for low temperature while annual rainfall has $1,317 \mathrm{~mm}$ and humidity of $72.0 \%$ (Thai Meteorological Department 2009). This province was recorded as a center of Thai indigenous chickens in many previous studies (Tungtakanpoung 2015; Soipeth et al. 2017; Yaemkong et al. 2017).

\section{Data collection and traits}

WTYC used for this study were reared semi-free range condition of rearing system which was described more detail in the study done by Kanta et al. (2018). A total of 209 adult male native chickens (WTYC) in Mueang District, Phitsanulok Province were randomly by purposive sampling. The phenotypic characteristics of chicken were described by using the field observation, direct measurement and photography method. WTYC were characterized phenotype of animal genetic resources under field conditions for qualitative and quantitative traits following FAO standard descriptors (FAO 2012). Eight qualitative traits were classified as beak color (BC), comb type (CT), neck plumage color (NPC), back plumage color (BPC), wing plumage color (WPC), long curving tail color (LCTC), back tails color (BTC) and shank color (SC). And seven quantitative traits were measured as body weight (BW; $\mathrm{kg})$, body height $(\mathrm{BH} ; \mathrm{cm})$, body length $(\mathrm{BL} ; \mathrm{cm})$, body width (BW; $\mathrm{cm}$ ), wing length (WL; $\mathrm{cm}$ ), shank length $(\mathrm{SL} ; \mathrm{cm})$ and toe length $(\mathrm{TL} ; \mathrm{cm})$.

\section{Statistical analysis}

The dataset was analyzed for characteristic diversity of phenotypes by using the Proc freq (qualitative traits) and Proc means (quantitative traits) procedure of Statistical Analysis System (SAS 2004), correlation among and between traits using the Proc corr procedure and factor affecting using the General Linear Model (GLM) procedure of SAS. Least squares mean for fixed effects and differences between subclasses within fixed effects were compared using a t-test at an $\alpha=0.05$ level.

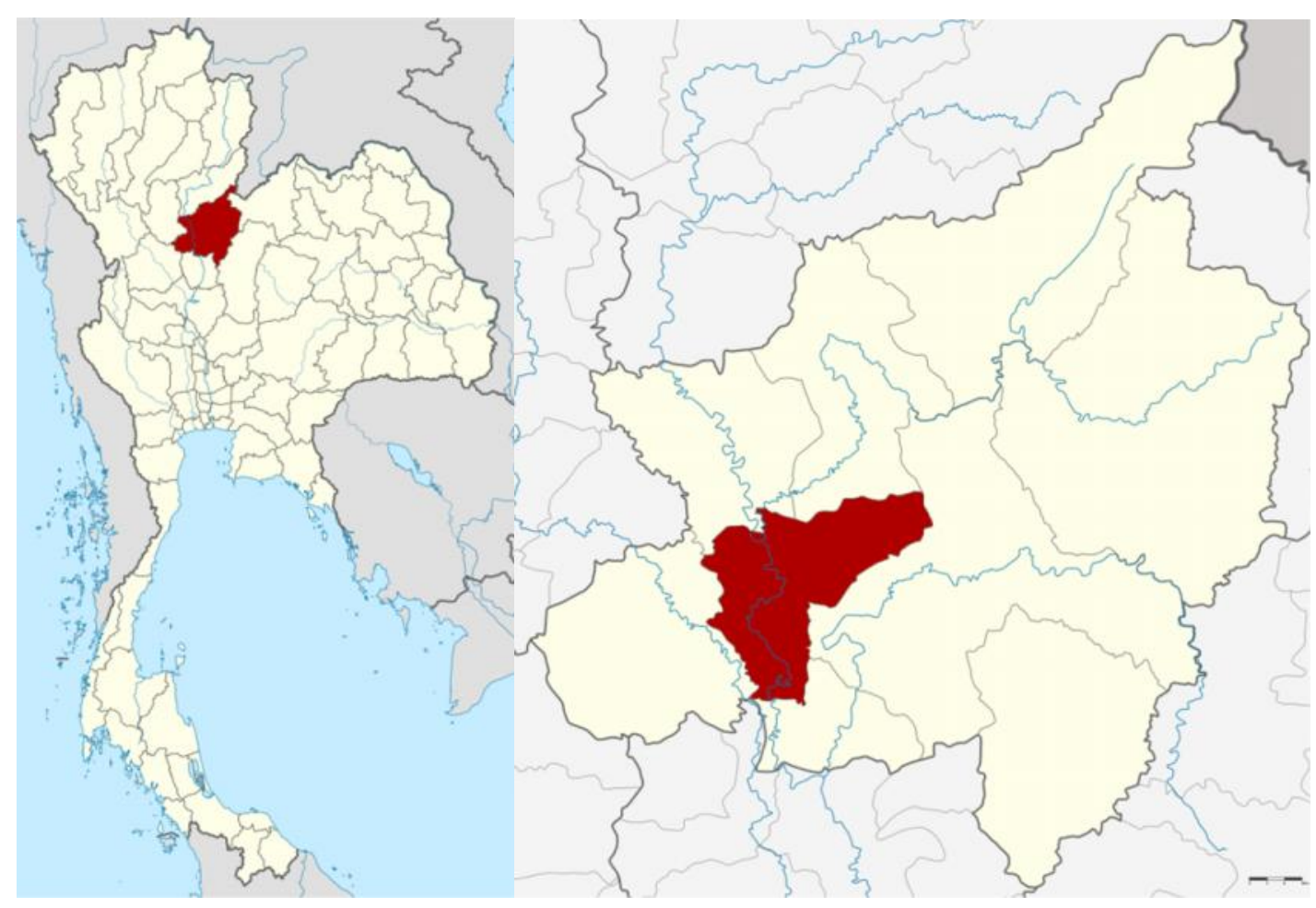

Figure 1. Map of Thailand, showing the location of Phitsanulok Province, Mueang District located in the lower of northern 


\section{RESULTS AND DISCUSSION}

\section{Diversity of qualitative traits}

The diversity of qualitative traits such as beak color, comb type, plumage color (neck plumage color, back plumage color, and wing plumage color), tail color (long curving tail color and back tail color) and shank color were shown in figure 2-8. The results revealed that the predominant beak color of chickens is white-yellow beak $(60.29 \%)$, followed by ivory beak $(24.88 \%)$ and yellow beak (14.83\%; Figure 2). This result similar to the results from Phitsanulok Provincial Livestock Office (2005) and Tungtakanpoung (2015) who reported that WTYC followed standard of perfection had white-yellow beak and also shank, toes, nails, and spurs. However, Chaiyachet et al. (2016) investigated the phenotypic characterization and identification of Thai native chicken breeds which mixedflock and sex in five districts of Maha Sarakham province. This found that most population of native chicken beak was black-yellow color. Similary, Kampala et al. (2016) studied on morphology of Thai native chickens of ethnic groups in Nan province. The result revealed that almost of male had black of beak color $(36.75 \%)$.

Three comb types, Hin, Pea, and Tum, were observed to occur in the order $65.50 \%, 27.00 \%$, and $7.50 \%$, respectively (Figure 3). It was in agreement with Tungtakanpoung (2015) reported that comb type of WTYC is Hin type. Although, Amnueysit et al. (2000b) showed diversity of local Thai cocks in Luang group at Muang district, Phichit province was Hin (32.77\%). Moreover, Yaemkong (2014) observed diversity of phenotypic characteristics of Thai indigenous chickens in 4 districts of Phitsanulok Province. It found that $89.46 \%$ of Hin comb in this study. But Rachsumpao (2004) found that more than $98.60 \%$ of comb type in male native chicken was Pea comb and whereas Single comb accounted for $1.40 \%$. However, Amnueysit et al. (2000a) reported that diversity of comb types in male local Thai cock at Muang district, Phichit province had 11 varieties such as Hin, Au, Ja/Jak, Wong duan, Bae, NokTakrum, Dhog-GonKai, Dhog Chaba, Bye Sre, Tum and Pea. These comb types characteristic resulting from Gene interaction (Tanchau 1995).

Two neck and back plumage colors (golden-yellow and orange) were identified among the WTYC in this area. Golden-yellow color had higher percentage $(95.69 \%$ and $96.17 \%$ ) than orange color (4.31\% and 3.83\%; Figure $4-5$ ). However, three wing plumage colors were obtained, golden-yellow (67.94\%), orange (30.14\%) and red (1.92\%), respectively (Figure 6). The results from the current study agreed with that of Tungtakanpoung (2015) who reported that King Narasuan's fighting chicken was beautiful at the plumage such as neck plumage, back plumage, and wing plumage. There was bright golden-yellow colors or Lueng Prapassorn all body (Phitsanulok Provincial Livestock Office 2005). These results were also in agreement with those studies by Rattanawaraha (1998) who found that most of plumage hair had yellow color. Moreover, Amnueysit et al. (2000b) revealed that the neck and wing plumage color ha a few mixing from other colors such as red, black and white-yellow color. The main back plumage color is yellow color but still found some of yellow-black, white, red, yellow-red, white-yellow and yellow-black colors. These occurred because it is hard to find the original breeding nowadays since farmers are not interested in pure breed that they prefer to produce cross breed with other exdigenous chickens. Additionally, free grazing chicken could lead to the variation of breeds, genes, and diversification of hybrid chickens. However, it was contrast for the fighting cock raisers who do not care much about the color of features and other phenotypic characterizations than origination of their chickens (Yaemkong 2014; Yaemkong and Tuan 2016). In another study, Akaravittayakun (1991) reported that a good fighting cock had the same plumage colors in their body and plumage colors was not related to fighting ability but it was attractive for many owner and local community.

Two long curving tail colors were observed in this study, with white-black having higher value $(70.11 \%)$ than white color (29.89\%; Figure 7 ). This result did not agree with those obtained by Phitsanulok Provincial Livestock Office (2005); Tungtakanpoung (2015) showing that one pair of the main middle of long curving tail hair had only white color and secondary long curving tail hair had more than 6 lines and white color. Moreover, three back tail colors were obtained, black color occurred highest $(71.15 \%)$ followed by white-black color $(25.37 \%)$ while white color occurred least $(3.48 \%$; Figure 8$)$. This is not also in agreement with the earlier report from Phitsanulok Provincial Livestock Office (2005) and Tungtakanpoung (2015) who indicated that the back tail colors had white color and more than 7 lines. This might happen when farmers raised another chicken such as Burma chicken together with native ones in the same farm (Amnueysit et al. 2000b). Rattanawaraha (1998) confirmed that back tail color was a indicator to classify breed and variety of native chicken to set the name of chicken suck as White Tailed-Yellow Chicken (Lueng Hang Khao) and Pradu Hang Dum Chicken.

In the current study, four shank colors (white-yellow, yellow, ivory and white, were observed for the WTYC with $59.81 \%, 23.92 \%, 11.48 \%$, and $4.79 \%$ respectively (Figure 9)). This result was similar to that reported by Rattanawaraha (1998)who stated that shank color had white-yellow. Normally, shank and break colors are similar color (white-yellow) and shank characteristic should have small slender and round (Phitsanulok Provincial Livestock Office 2005; Tungtakanpoung 2015). On the other hands, Amnueysit et al. (2000b); Rachsumpao (2004); Thinh et al. (2015) reported that the majority of shank color in WTYC, Native male Chicken and male Native Chicken at Vietnam were $96.56 \%, 43.75 \%$, and $97.00 \%$, respectively. Furthermore, Laenoi et al. (2015) found that the predominant of shank color of indigenous chicken in the highland region of Phayao was black color (55.60\%). However, Tancho (1995) reported that shank color characteristic depended on pigment in level of skin. If those chickens had more carotenoid, it will be yellow shank color but if those chicken had more melanic, it will be gray and black shank colors. 


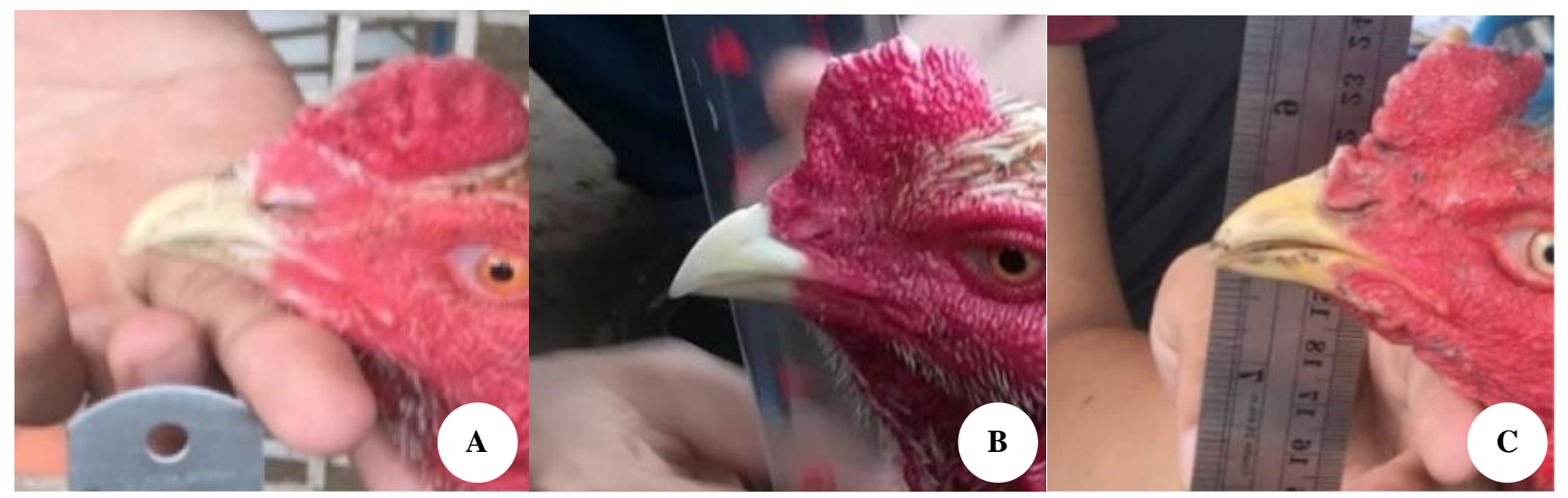

Figure 2. The phenotypic characteristics of beak color (A) White-yellow (B) Ivory and (C) Yellow

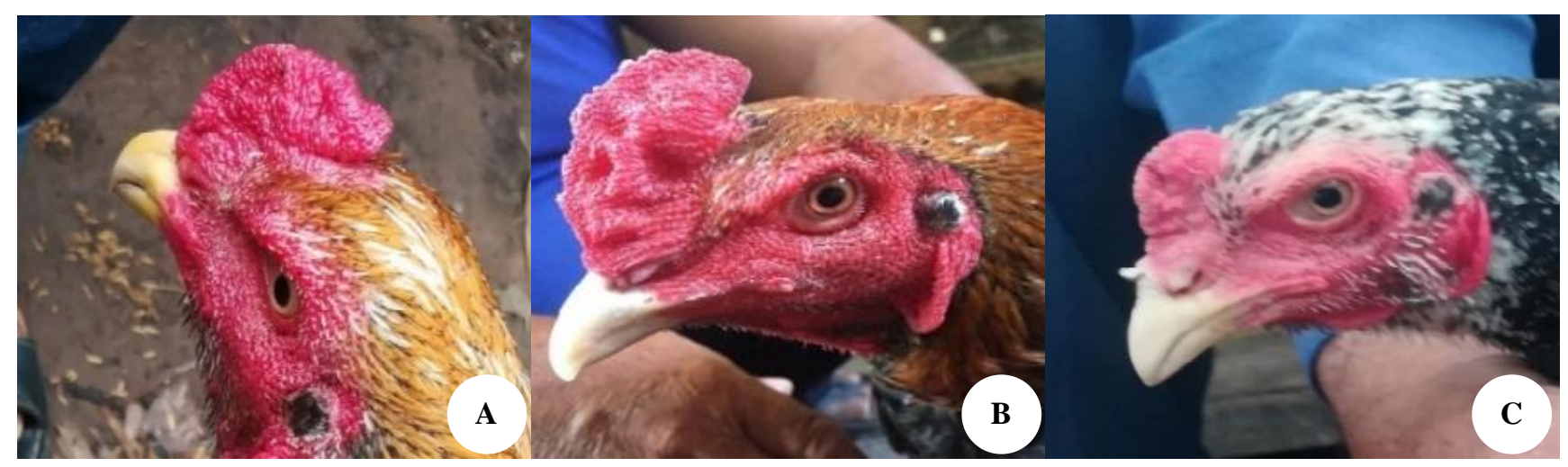

Figure 3. The phenotypic characteristics of comb types (A) Hin (B) Pea and (C) Tum

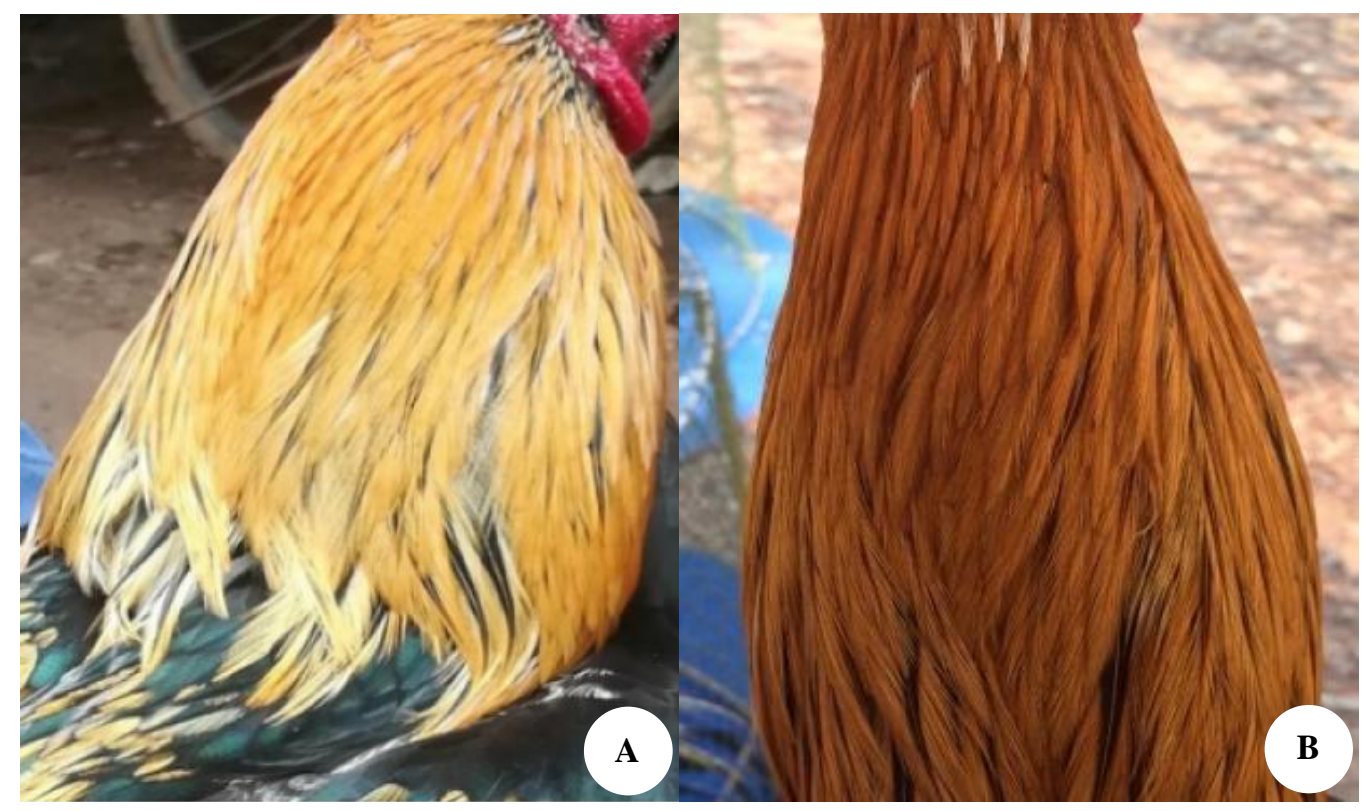

Figure 4. The phenotypic characteristics of neck plumage color (A) Golden-yellow and (B) Orange 


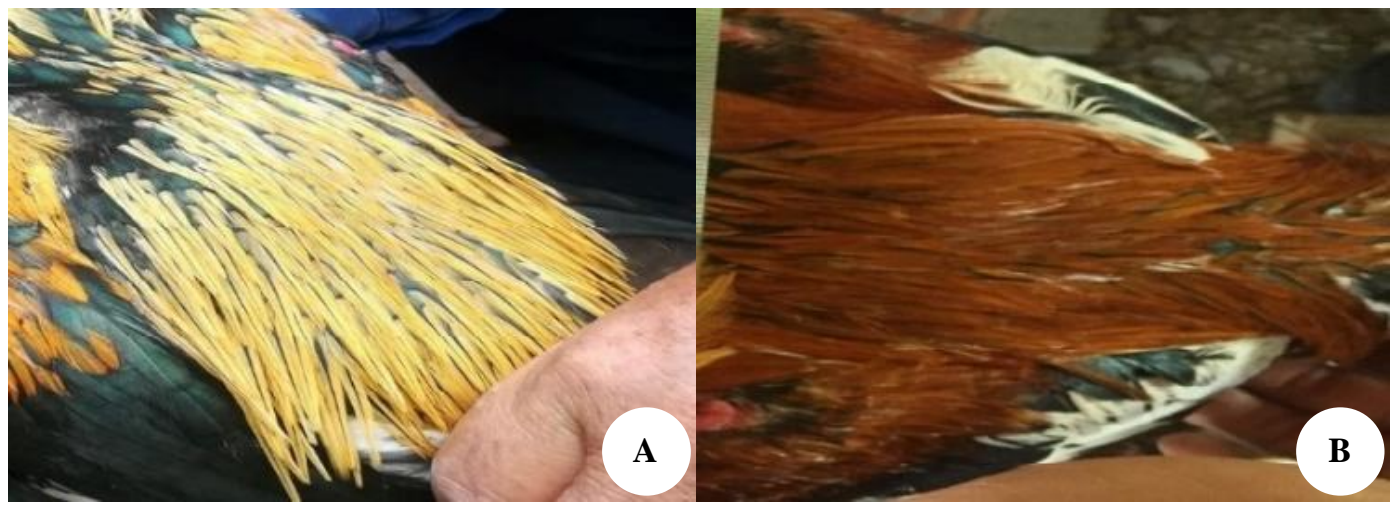

Figure 5. The phenotypic characteristics of back plumage color (A) Golden-yellow and (B) Orange

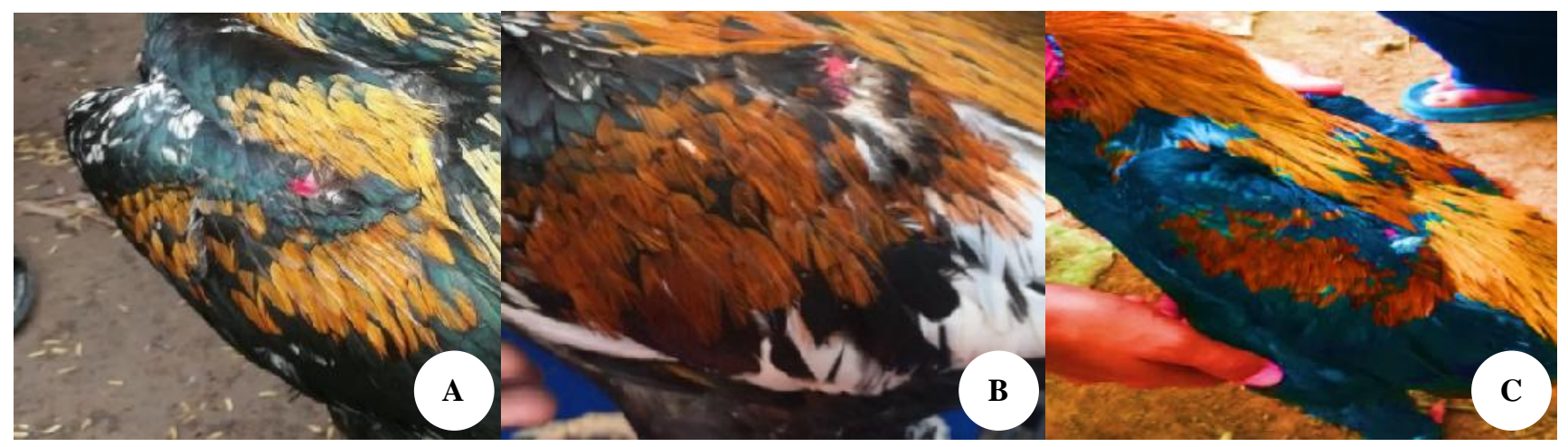

Figure 6. The phenotypic characteristics of wing plumage color (A) Golden-yellow (B) Orange and (C) Red

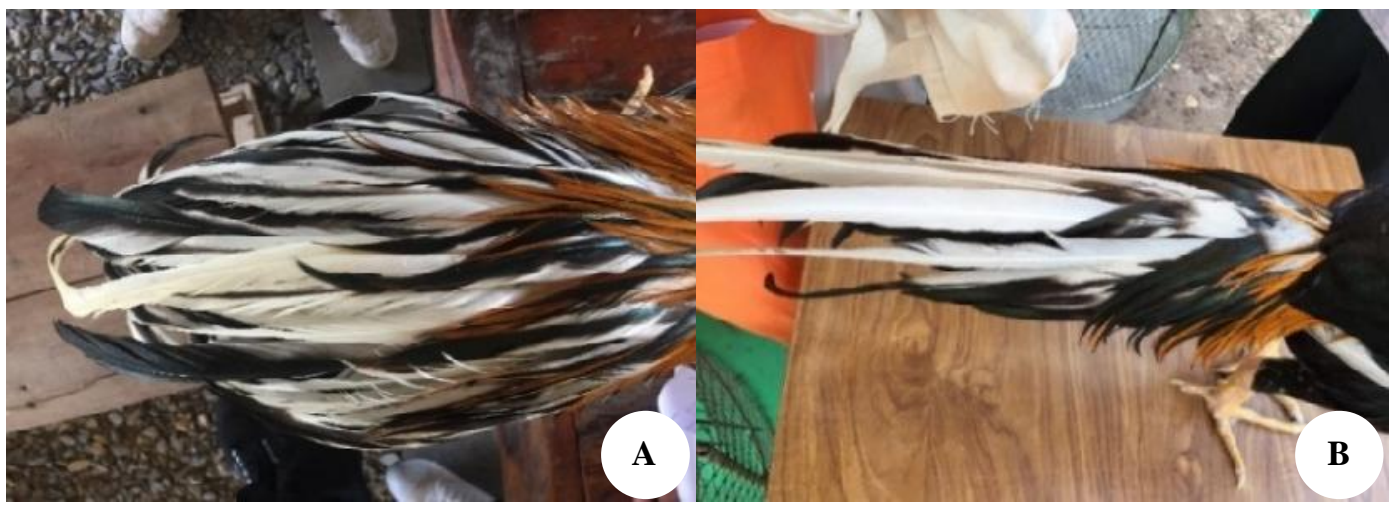

Figure 7. The phenotypic characteristics of long curving tails color (A) White-black and (B) White

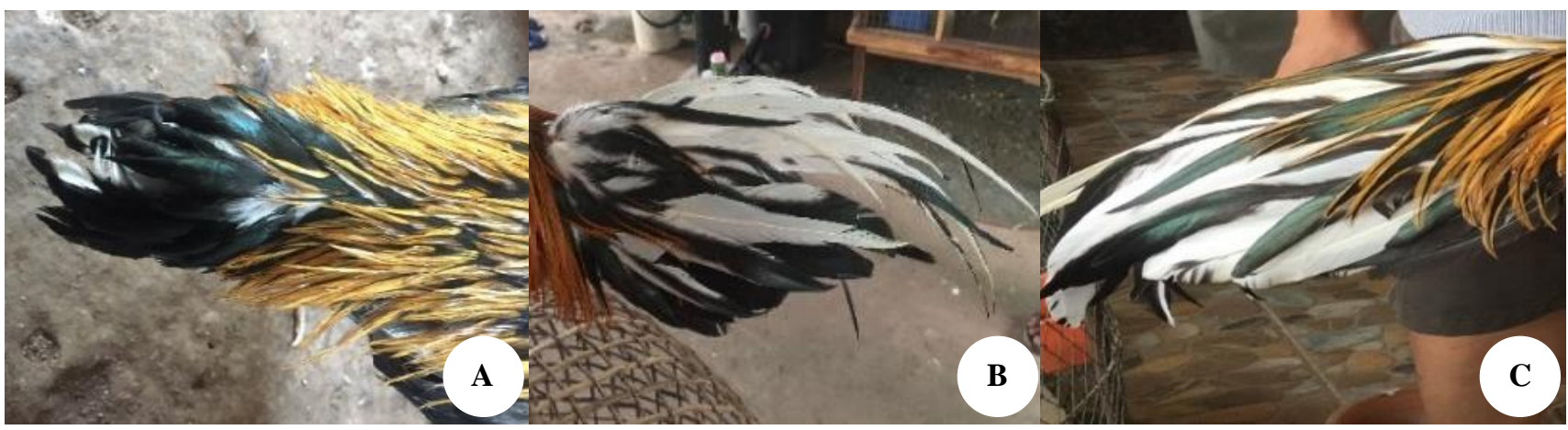

Figure 8. The phenotypic characteristics of back tails color (A) Black (B) White-black and (C) White 


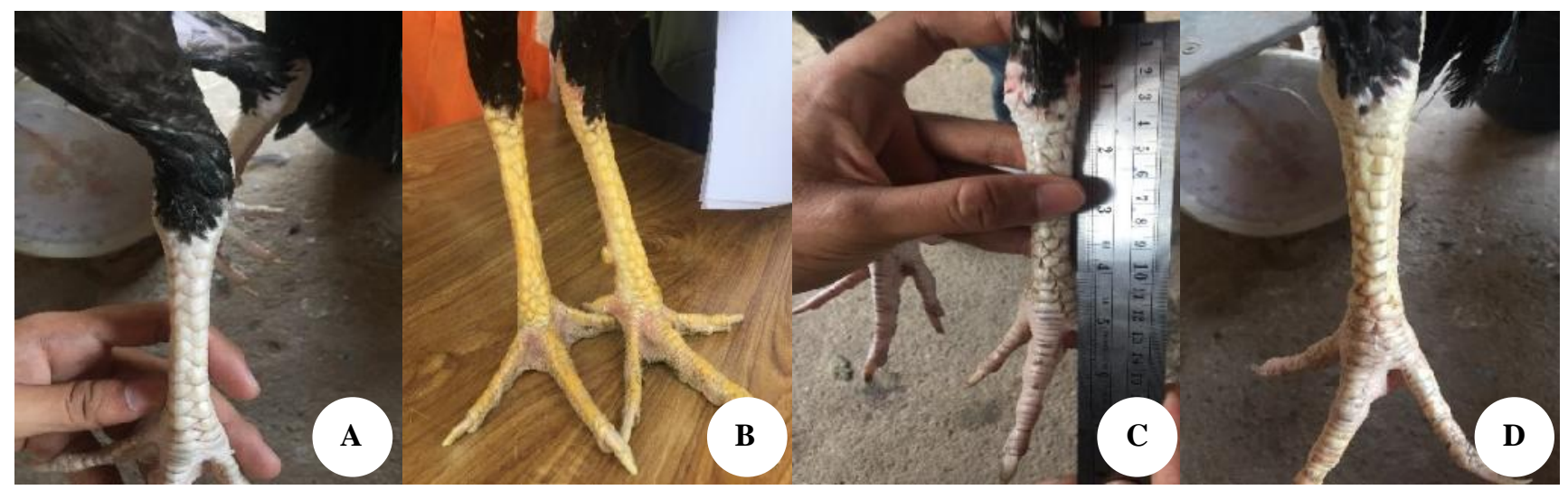

Figure 9. The phenotypic characteristics of shank color (A) White-yellow (B) Yellow (C) Ivory and (D) White

Table 1. Least Square Means (LSM) and standard errors for quantitative traits of White Tailed-Yellow Chicken in Mueang District, Phitsanulok Province, Thailand

\begin{tabular}{lc}
\hline Quantitative traits & $\begin{array}{c}\text { Least Square Means } \pm \\
\text { standard errors }\end{array}$ \\
\hline Body weight $(\mathrm{kg})$ & $2.78 \pm 0.58$ \\
Body height $(\mathrm{cm})$ & $61.95 \pm 3.77$ \\
Body length $(\mathrm{cm})$ & $24.93 \pm 1.66$ \\
Body width $(\mathrm{cm})$ & $16.62 \pm 1.91$ \\
Wing length $(\mathrm{cm})$ & $41.85 \pm 2.52$ \\
Shank length $(\mathrm{cm})$ & $12.72 \pm 0.77$ \\
Toes length $(\mathrm{cm})$ & $8.39 \pm 0.66$ \\
\hline
\end{tabular}

\section{Diversity of quantitative traits}

The variation of quantitative traits such as body weight, body height, body length, body width, wing length, shank length, and toes length were measured for WTYC population which were shown in Table 1.

The data in Table 1 were close to values for male WTYC in Phitsanulok Province reported by Soipeth et al. (2017) in which body weight, body height, body length, wing length, shank length, and toes length were $3.27 \pm 0.56$ $\mathrm{kg}, 62.21 \pm 4.76 \mathrm{~cm}, 24.03 \pm 3.14 \mathrm{~cm}, 44.95 \pm 3.85 \mathrm{~cm}$, $13.05 \pm 1.03 \mathrm{~cm}$, and $9.19 \pm 0.77 \mathrm{~cm}$. In contrast, Laenoi et al. (2015) reported that male native chicken in Phayao province had $1.95 \pm 0.25 \mathrm{~kg}$ of body weight. Another study, Soipeth et al. (2017) reported that male WTYC in Phitsanulok Province had $31.82 \pm 4.47 \mathrm{~cm}$. of body width. Abinawanto et al. (2017) also reported that body weight, shank length, and wing length were $1.67 \mathrm{~kg}, 11.26 \mathrm{~cm}$, and $23.21 \mathrm{~cm}$, respectively for morphometric characters of Gaga chicken from Pinrang, South Sulawesi, Indonesia. Moreover, Phitsanulok Provincial Livestock Office (2005); Biodiversity Research section (2012) and Tungtakanpoung (2015) stipulated standard characteristic of WTYC that average body weight of male chicken was more than $3 \mathrm{~kg}$ and body height was $45 \mathrm{~cm}$. Similarly, the result in this study recorded for $61.95 \pm 3.77 \mathrm{~cm}$ of body height, higher than that characterized for standard characteristics whereas the body weight was less. This might cause of difference in the age of chickens. WTYC in this study was $7.40 \pm 5.00$ months whereas Singh et al. (2016) reported in their study was 1 year old and Amnueysit et al. (2000b) studied on chickens with age of 13.99 months and Soipeth et al. (2017) reported for the age of 18-36 months for native chicken in Phitsanulok Province. Additionally, Choprakarn (2000) reported that characteristic of Thai native chicken was higher and slimmer than broiler and adult of male native chicken was $3.0-3.5 \mathrm{~kg}$ of average body weight.

\section{Correlation among qualitative traits}

Correlations among the quantitative traits of WTYC population are demonstrated in Table 2. The result was showed significant strong positive relationships between neck plumage color and back plumage color $(\mathrm{r}=0.70$; $\mathrm{p}<0.01)$, and between beak color and shank color $(\mathrm{r}=0.60$; $\mathrm{p}<0.01$ ). Additionally, weak positive relationships between back plumage color and wing plumage color $(\mathrm{r}=0.26$; $\mathrm{p}<0.01$ ), and neck plumage color and wing plumage color $(\mathrm{r}=0.18 ; \mathrm{p}<0.01)$.

These results were similar to those reported by Phitsanulok Provincial Livestock Office (2005) and Tungtakanpoung (2015) in which they stated that WTYC following standard of perfection of beak color was closely associated with shank color and between plumage color (neck, back and wing plumage colors) i.e. neck plumage color was strongly associated with back plumage color, while wing plumage color was associated with neck and back plumage colors. Whereas, Tabassum et al. (2014) reported that bird and comb type, shank, eggshell, earlobe, skin and plumage color had no significant correlation between each other. So bird type, plumage color, shank color or eggshell color did not affect each other significantly of indigenous chickens at Jhenigati Upazilla of Sherpur district in Bangladesh. However, Guni et al. (2013) reported that plumage color was closely associated with shank and earlobe color, shank color was associated with skin and earlobe color, while earlobe color was associated with comb type in Tanzanian chicken.

\section{Correlation among quantitative traits}

Correlations among the quantitative traits of WTYC population are presented in Table 3. All positive relationships among the studied quantitative traits were significant $(\mathrm{r}=0.23$ to $0.58 ; \mathrm{p}<0.01)$. 
Table 2. Correlation among qualitative traits of White Tailed-Yellow Chicken in Mueang District, Phitsanulok Province, Thailand

\begin{tabular}{|c|c|c|c|c|c|c|c|c|}
\hline Qualitative traits & $\begin{array}{l}\text { Beak } \\
\text { color }\end{array}$ & Come type & $\begin{array}{c}\text { Neck } \\
\text { plumage } \\
\text { color }\end{array}$ & $\begin{array}{c}\text { Back } \\
\text { plumage } \\
\text { color } \\
\end{array}$ & $\begin{array}{c}\text { Wing } \\
\text { plumage } \\
\text { color } \\
\end{array}$ & $\begin{array}{c}\text { Long } \\
\text { curving } \\
\text { tail color }\end{array}$ & $\begin{array}{l}\text { Back tail } \\
\text { color }\end{array}$ & $\begin{array}{l}\text { Shank } \\
\text { color }\end{array}$ \\
\hline Beak color & 1.00 & 0.10 & -0.07 & -0.03 & -0.00 & -0.01 & -0.03 & $0.60 * *$ \\
\hline Come type & 0.10 & 1.00 & -0.06 & 0.00 & -0.08 & 0.01 & 0.07 & 0.06 \\
\hline Neck plumage color & -0.07 & -0.06 & 1.00 & $0.70 * *$ & $0.18 * *$ & -0.21 & -0.05 & -0.18 \\
\hline Back plumage color & -0.03 & 0.00 & $0.70 * *$ & 1.00 & $0.26 * *$ & -0.11 & 0.03 & -0.07 \\
\hline Wing plumage color & -0.00 & -0.08 & $0.18 * *$ & $0.26 * *$ & 1.00 & -0.01 & -0.14 & -0.02 \\
\hline $\begin{array}{l}\text { Long curving tail } \\
\text { color }\end{array}$ & -0.01 & 0.01 & -0.21 & -0.12 & -0.01 & 1.00 & 0.09 & -0.08 \\
\hline Back tail color & -0.03 & 0.07 & -0.05 & 0.03 & -0.14 & 0.09 & 1.00 & -0.08 \\
\hline Shank color & $0.60 * *$ & 0.06 & -0.18 & -0.07 & -0.02 & -0.08 & -0.08 & 1.00 \\
\hline
\end{tabular}

Note: $* *$ Correlation is significant at $0.01 \%$ level.

Table 3. Correlation among quantitative traits of White Tailed-Yellow Chicken in Mueang District, Phitsanulok Province, Thailand

\begin{tabular}{|c|c|c|c|c|c|c|c|}
\hline $\begin{array}{l}\text { Quantitative } \\
\text { traits }\end{array}$ & Body weight & Body height & Body length & Body width & Wing length & Shank length & Toe length \\
\hline Body weight & 1.00 & $0.48 * *$ & $0.31 * *$ & $0.57 * *$ & $0.58 * *$ & $0.33 * *$ & $0.37 * *$ \\
\hline Body height & $0.48 * *$ & 1.00 & $0.49 * *$ & $0.47 * *$ & $0.52 * *$ & $0.47 * *$ & $0.40 * *$ \\
\hline Body length & $0.31 * *$ & $0.49 * *$ & 1.00 & $0.44 * *$ & $0.48 * *$ & $0.37 * *$ & $0.30 * *$ \\
\hline Body width & $0.57 * *$ & $0.47 * *$ & $0.44 * *$ & 1.00 & $0.54 * *$ & $0.23 * *$ & $0.38 * *$ \\
\hline Wing length & $0.58 * *$ & $0.52 * *$ & $0.48 * *$ & $0.54 * *$ & 1.00 & $0.31 * *$ & $0.29 * *$ \\
\hline Shank length & $0.33 * *$ & $0.47 * *$ & $0.37 * *$ & $0.23 * *$ & $0.31 * *$ & 1.00 & $0.45 * *$ \\
\hline Toe length & $0.37 * *$ & $0.40 * *$ & $0.30 * *$ & $0.38 * *$ & $0.29 * *$ & $0.45 * *$ & 1.00 \\
\hline
\end{tabular}

Note: $* *$ Correlation is significant at $0.01 \%$ level

Table 4. Correlation among qualitative and quantitative traits of White Tailed-Yellow Chicken in Mueang District, Phitsanulok Province, Thailand

\begin{tabular}{|c|c|c|c|c|c|c|c|}
\hline Traits & $\begin{array}{l}\text { Body } \\
\text { weight }\end{array}$ & $\begin{array}{l}\text { Body } \\
\text { height }\end{array}$ & Body length & $\begin{array}{l}\text { Body } \\
\text { width }\end{array}$ & Wing length & $\begin{array}{l}\text { Shank } \\
\text { length }\end{array}$ & Toe length \\
\hline Beak color & 0.01 & $0.14^{*}$ & 0.08 & 0.04 & 0.07 & -0.06 & -0.06 \\
\hline Come type & 0.06 & 0.04 & 0.05 & -0.05 & -0.08 & -0.09 & -0.11 \\
\hline Neck plumage color & $0.16^{*}$ & -0.05 & 0.08 & $0.19 * *$ & 0.06 & 0.05 & 0.07 \\
\hline Back plumage color & 0.11 & 0.04 & 0.02 & 0.03 & 0.04 & 0.06 & -0.04 \\
\hline Wing plumage color & 0.03 & $0.15^{*}$ & $0.21 * *$ & $0.18^{*}$ & 0.05 & 0.09 & 0.06 \\
\hline Long curving tail color & $-0.27 * *$ & $-0.28 * *$ & -0.11 & $-0.21 * *$ & $-0.16^{*}$ & $-0.16^{*}$ & $-0.24 * *$ \\
\hline Back tail color & $-0.24 * *$ & $-0.20 * *$ & -0.02 & $-0.28 * *$ & $-0.15^{*}$ & -0.03 & -0.08 \\
\hline Shank color & $0.14 *$ & $0.19 * *$ & 0.04 & 0.00 & 0.04 & 0.00 & -0.00 \\
\hline
\end{tabular}

Note: *Correlation is significant at $0.05 \%$ level and $* *$ Correlation is significant at $0.01 \%$ level

The results from correlation among quantitative traits were in the same line with Gueye et al. (1998) who reported that the correlations between body length and live weight were $(r=0.33)$ positive significantly $(p<0.01)$ in Senegalese chicken. Moreover, Apuno et al. (2011) found significant correlation between body weight, back length and body circumference in Nigerian indigenous chicken. According to Alabi et al. (2012), body weight was highly correlated with linear body measurements in Naked Neck and Venda chickens and it was non-significant ( $p>0.01)$ in Koekoek chicken of South Africa. In another study, Tabassum et al. (2014) also reported that the highest correlation (0.70) between body weight and body circumference, followed by correlation (0.36) between body weight and back length, and correlation (0.27) between body weight and pelvis width were observed. But there was no significant correlation between back length and body circumference, back length and pelvis width, and body circumference and pelvis width. On the other hands, Faruque et al. (2010) reported high degree of correlation between body weight and linear body measurements and they observed the best correlation in Naked Neck chicken, while Daikwo et al. (2011) found body weight of chicken in Dekina highly correlated with back length and body circumference. Therefore, results of the present study and findings of other scientists suggested that selection for any of these linear body measurements will cause direct improvement in body weight. 


\section{Correlation between qualitative and quantitative traits}

There was no significant correlation between qualitative and quantitative traits of WTYC, except for some traits that correlation between traits was significant $(p<0.05)$, as shown in Table 4.

Results from this study demonstrated the positive correlation of beak color with body height $(\mathrm{r}=0.14)$, neck plumage color with body weight $(\mathrm{r}=0.16)$ and body width $(\mathrm{r}=0.19)$, wing plumage color with body height $(\mathrm{r}=0.15)$, body length $(\mathrm{r}=0.21)$ and body width $(\mathrm{r}=0.18)$, and shank color with body weight $(\mathrm{r}=0.14)$ and body height $(\mathrm{r}=0.19$; Table 4) were significant $(\mathrm{p}<0.05)$. And also negative correlation of long curving tail color with body weight $(\mathrm{r}=$ $0.27)$, body height $(\mathrm{r}=-0.28)$, body width $(\mathrm{r}=-0.21)$, wing length $(\mathrm{r}=-0.16)$, shank length $(\mathrm{r}=-0.16)$ and toe length $(\mathrm{r}=-$ 0.24 ), back tail color with body weight ( $\mathrm{r}=-0.24)$, body height $(\mathrm{r}=-0.20)$, body width $(\mathrm{r}=-0.28)$ and wing length $(\mathrm{r}=-$ 0.15 ; Table 4) were significant $(\mathrm{p}<0.05)$. However, this study is suggesting the possibility in the reduction of specific long curving tail color with the increase of body weight, body height, body width, wing length, shank length and toe length, and back tail color with the increase of body weight, body height, body width, and wing length. Additionally, Tabassum et al. (2014) reported that there was no significant correlation between phenotypic traits and morphometric traits except correlation of eggshell color with body weight, body circumference, and pelvis width. However, eggshell color was significantly correlated with body weight $(-0.48)$, body circumference $(-0.41)$ and pelvis width $(-0.26)$. On the contrary, Buvanendran and Merritt (2011) observed a consistent trend towards a darker egg shell color with increasing body weight in meat-type chicken.

\section{Effects of qualitative traits on quantitative traits}

Table 5 summarises qualitative and quantitative traits of the chicken. Beak color and come type had no significant effect on body weight, body height, body length, body width, wing length, shank length and toe length ( $p>0.05)$. Result from come type was in agreement with that reported by Tabassum et al. (2014) who found comb type had no significant effect on back length and body circumference, but body weight and pelvis width of indigenous chickens in Bangladesh were significantly affected, but Apuno et al. (2011) found no significant $(p>0.05)$ effect in Senegalese chicken. However, comb size of dam had not significant influence on day-old chick weight, 6th-week chick weight and 11th-week chick weight (Haq et al. 2003).

Table 5. Least squares means and standard errors for and qualitative and quantitative traits of White Tailed-Yellow Chicken in Mueang District, Phitsanulok Province, Thailand

\begin{tabular}{|c|c|c|c|c|c|c|c|}
\hline Traits & $\begin{array}{c}\text { Body weight } \\
\text { (kg) }\end{array}$ & $\begin{array}{c}\text { Body height } \\
(\mathrm{cm})\end{array}$ & $\begin{array}{c}\text { Body length } \\
(\mathrm{cm})\end{array}$ & $\begin{array}{c}\text { Body width } \\
\text { (cm) }\end{array}$ & $\begin{array}{c}\text { Length wing } \\
(\mathrm{cm})\end{array}$ & $\begin{array}{c}\text { Length shank } \\
(\mathrm{cm})\end{array}$ & $\begin{array}{c}\text { Length toe } \\
(\mathrm{cm})\end{array}$ \\
\hline Beak color & 0.3687 & 0.6840 & 0.5557 & 0.9370 & 0.5520 & 0.8609 & 0.8791 \\
\hline Yellow & $3.32 \pm 0.23$ & $62.05 \pm 1.27$ & $24.58 \pm 0.60$ & $16.77 \pm 0.66$ & $41.32 \pm 0.95$ & $13.05 \pm 0.30$ & $8.57 \pm 0.26$ \\
\hline White-yellow & $3.14 \pm 0.20$ & $62.74 \pm 1.12$ & $24.96 \pm 0.53$ & $16.72 \pm 0.58$ & $42.04 \pm 0.84$ & $13.02 \pm 0.26$ & $8.51 \pm 0.23$ \\
\hline Ivory & $3.06 \pm 0.22$ & $62.94 \pm 1.26$ & $24.68 \pm 0.60$ & $16.59 \pm 0.66$ & $42.01 \pm 0.94$ & $13.11 \pm 0.30$ & $8.46 \pm 0.26$ \\
\hline Come type & 0.6789 & 0.6015 & 0.3344 & 0.2430 & 0.2131 & 0.7440 & 0.4967 \\
\hline Hin & $3.12 \pm 0.19$ & $62.22 \pm 1.07$ & $24.68 \pm 0.51$ & $16.77 \pm 0.56$ & $42.04 \pm 0.80$ & $13.08 \pm 0.25$ & $8.59 \pm 0.22$ \\
\hline Pea & $3.19 \pm 0.21$ & $62.74 \pm 1.15$ & $25.04 \pm 0$ & $17.09 \pm 0.60$ & $41.31 \pm 0.86$ & $12.98 \pm$ & $8.46 \pm 0.23$ \\
\hline Tum & $3.21 \pm 0.24$ & $62.76 \pm 1.26$ & $24.49 \pm 0.66$ & $16.22 \pm 0.72$ & $42.03 \pm 1.03$ & $13.11 \pm 0.33$ & $8.50 \pm 0.28$ \\
\hline Neck plumage color & 0.1784 & $0.0174 *$ & 0.3332 & $0.0039 *$ & 0.9074 & 0.6394 & 0.1004 \\
\hline Golden-yellow & $2.98 \pm 0.21$ & $64.54 \pm 1.25$ & $24.36 \pm 0.59$ & $15.45 \pm 0.65$ & $41.86 \pm 0.93$ & $13.15 \pm 0.29$ & $8.24 \pm 0.25$ \\
\hline Orange & $3.36 \pm 0.27$ & $60.61 \pm 1.48$ & $25.11 \pm 0.70$ & $17.93 \pm 0.77$ & $41.72 \pm 1.10$ & $12.97 \pm 0.35$ & $8.79 \pm 0.30$ \\
\hline Back plumage color & 0.8728 & 0.1770 & 0.1486 & $0.0082 *$ & 0.7976 & 0.4614 & 0.0993 \\
\hline Golden-yellow & $3.15 \pm 0.20$ & $61.41 \pm 1.16$ & $25.33 \pm 0.55$ & $17.88 \pm 0.60$ & $41.63 \pm 0.87$ & $12.91 \pm 0.27$ & $8.81 \pm 0.24$ \\
\hline Orange & $3.20 \pm 0.28$ & $63.74 \pm 1.59$ & $24.15 \pm 0.76$ & $15.49 \pm 0.83$ & $41.96 \pm 1.19$ & $13.21 \pm 0.37$ & $8.22 \pm 0.32$ \\
\hline Wing plumage color & 0.8121 & 0.1776 & $0.0473 *$ & 0.1020 & 0.9179 & 0.6682 & 0.5475 \\
\hline Golden-yellow & $3.19 \pm 0.17$ & $61.93 \pm 0.97$ & $24.11 \pm 0.46$ & $16.42 \pm 0.50$ & $41.82 \pm 0.72$ & $12.98 \pm 0.23$ & $8.42 \pm 0.20$ \\
\hline Orange & $3.24 \pm 0.17$ & $63.01 \pm 0.95$ & $24.71 \pm 0.45$ & $17.08 \pm 0.49$ & $41.98 \pm 0.70$ & $13.10 \pm 0.22$ & $8.56 \pm 0.19$ \\
\hline Red & $3.08 \pm 0.36$ & $62.78 \pm 2.09$ & $25.40 \pm 0.99$ & $16.57 \pm 1.09$ & $41.58 \pm 1.56$ & $13.09 \pm 0.49$ & $8.56 \pm 0.43$ \\
\hline Long curving tail color & $0.0055^{*}$ & $<0.001 *$ & 0.0613 & $0.0033 *$ & $0.0296 *$ & 0.0642 & $0.0022 *$ \\
\hline White-black & $3.31 \pm 0.19^{\mathrm{a}}$ & $63.77 \pm 1.11$ & $24.99 \pm 0.53$ & $17.13 \pm 0.58$ & $42.25 \pm 0.83$ & $13.18 \pm 0.26$ & $8.69 \pm 0.22$ \\
\hline White & $3.04 \pm 0.21^{\mathrm{b}}$ & $61.38 \pm 1.16$ & $24.49 \pm 0.55$ & $16.25 \pm 0.60$ & $41.33 \pm 0.87$ & $12.94 \pm 0.27$ & $8.34 \pm 0.24$ \\
\hline Back tail color & $0.0169 *$ & $0.0217 *$ & 0.2263 & $<0.0001$ & $0.0227 *$ & 0.4525 & 0.5240 \\
\hline White & $3.18 \pm 0.20^{\mathrm{b}}$ & $62.83 \pm 1.68$ & $24.20 \pm 0.80$ & $16.58 \pm 0.87$ & $41.54 \pm 1.25$ & $13.30 \pm 0.39$ & $8.32 \pm 0.34$ \\
\hline White-black & $3.39 \pm 0.29^{\mathrm{a}}$ & $63.24 \pm 1.11$ & $25.19 \pm 0.53$ & $17.43 \pm 0.58$ & $42.52 \pm 0.83$ & $12.89 \pm 0.26$ & $8.64 \pm 0.23$ \\
\hline Black & $2.94 \pm 0.19^{c}$ & $61.65 \pm 1.04$ & $24.82 \pm 0.50$ & $16.06 \pm 0.54$ & $41.32 \pm 0.78$ & $12.99 \pm 0.24$ & $8.57 \pm 0.21$ \\
\hline Shank color & & 0.5364 & 0.1907 & 0.18 & 0.4882 & 0.6309 & 0.4907 \\
\hline Yellow & $3.04 \pm 0.2$ & $62.13 \pm 1.1$ & $25.21 \pm 0.55$ & $17.28 \pm 0.60$ & $42.40 \pm 0.86$ & $13.04 \pm 0.27$ & $8.36 \pm 0.24$ \\
\hline White & $2.87 \pm 0.34$ & $62.71 \pm 1.98$ & $23.36 \pm$ & $15.32 \pm 1.03$ & $40.53 \pm 1.47$ & $13.40=$ & $8.92 \pm 0.40$ \\
\hline White-yellow & $3.36 \pm 0.20$ & $63.12 \pm 1.15$ & $25.07 \pm 0.55$ & $17.23 \pm 0.60$ & $42.37 \pm 0.86$ & $13.01 \pm 0.27$ & $8.37 \pm 0.23$ \\
\hline Ivory & $3.42 \pm 0.24$ & $62.33 \pm 1.35$ & $25.32 \pm 0.64$ & $16.92 \pm 0.70$ & $41.87 \pm 1.00$ & $12.78 \pm 0.31$ & $8.41 \pm 0.27$ \\
\hline
\end{tabular}

Note: "Means with a superscript in a row are significantly different $(\mathrm{p}<0.05)$ 
Neck plumage color had significant effect on body height and body width $(\mathrm{p}<0.05)$, golden-yellow neck plumage color had higher body height $(64.54 \pm 1.25 \mathrm{~cm})$, than orange color $(60.61 \pm 1.48 \mathrm{~cm})$. On the other hand, orange neck plumage color had higher body width $(17.93 \pm$ $0.77 \mathrm{~cm})$, than golden-yellow color $(15.45 \pm 0.65 \mathrm{~cm})$. Moreover, back plumage color and wing plumage color had significant effect on body width and body length, respectively $(\mathrm{p}<0.05)$. Golden-yellow back plumage color had higher body width $(17.88 \pm 0.60 \mathrm{~cm})$, than orange color $(15.49 \pm 0.83 \mathrm{~cm})$. And red wing plumage color had the highest body length $(25.40 \pm 0.99 \mathrm{~cm})$, followed by orange color $(24.71 \pm 0.45 \mathrm{~cm})$ and golden-yellow color $(24.11 \pm 0.46 \mathrm{~cm})$. These results were similar with Tabassum et al. (2014) who reported that plumage colors did not affect body weight, back length, body circumference, and pelvis width significantly but Sarker et al. (2014) found significant effect of plumage color on body weight of Indigenous chicken in Bangladesh. Moreover, several investigators who found significant effect of plumage colors on back length and body circumference in Senegalese chicken (Apuno et al. 2011) and also found significant effect of specific plumage colors and age groups ( $p<0.05$ and $p<0.01$, respectively) on egg production (Shahjahan et al. 2011)

Long curving tail color had significant effect on body weight, body height, body width, wing length and toe length $(p<0.05)$, except for body length and shank length ( $>00.05$ ). White-black long curving tail color had higher body weight, body height, body width, wing length and toe length than white color $(3.31 \pm 0.19$ vs $3.04 \pm 0.21 \mathrm{~kg}$, $63.77 \pm 1.11$ vs $61.38 \pm 1.16 \mathrm{~cm}, 17.13 \pm 0.58$ vs $16.25 \pm$ $0.60 \mathrm{~cm}, 42.25 \pm 0.83$ vs $41.33 \pm 0.87 \mathrm{~cm}$ and $8.69 \pm 0.22$ vs $8.34 \pm 0.24 \mathrm{~cm}$, respectively). And back tail color had significant effect on body weight, body height and length wing $(\mathrm{p}<0.05)$, except for body length, body width, shank length and toe length ( $p>0.05)$. White-black back tail color had the highest body weight $(3.39 \pm 0.29 \mathrm{~kg})$, body height $(63.24 \pm 1.11 \mathrm{~cm})$ and wing length $(42.52 \pm 0.83 \mathrm{~cm})$ followed by white color $(3.18 \pm 0.20 \mathrm{~kg}$ vs $62.83 \pm 1.68 \mathrm{~cm}$ vs $61.65 \pm 1.04 \mathrm{~cm})$ and black color $(2.94 \pm 0.19 \mathrm{~kg}$ vs $41.54 \pm 1.25 \mathrm{~cm}$ vs $41.32 \pm 0.78 \mathrm{~cm}$ ), respectively.

Shank color had no significant effect on body height, body length, body width, wing length, shank length and toe length $(\mathrm{p}>0.05)$, except for body weight $(\mathrm{p}<0.05)$. Ivory shank color had the highest body weight $(3.42 \pm 0.24 \mathrm{~kg})$, followed by white-yellow color $(3.36 \pm 0.20 \mathrm{~kg})$, yellow color $(3.04 \pm 0.20 \mathrm{~kg})$ and white color $(2.87 \pm 0.34 \mathrm{~kg})$, respectively. This was on the contrary to what was reported by Tabassum et al. (2014) that shank colors had no significant effect on body weight, back length, body circumference, and pelvis width. Besides, Apuno et al (2011) also found no significant effect on body weight and back length in Senegalese chickens.

In conclusion, this study confirmed that the qualitative traits of WTYC had the highest white-yellow beak, hin comb, golden-yellow neck plumage, back plumage and wing plumage, white-black long curving tails, black back tails, and white-yellow shank. The highest positive correlation was observed between neck plumage color and back plumage color $(\mathrm{p}<0.01)$. Moreover, body weight was significantly highest correlated with wing length $(p<0.01)$ and body length was significantly highest positive correlated with wing plumage color $(\mathrm{p}<0.01)$. However, beak color and come type had no significant effect on all traits ( $>0.05)$ except for neck, back and wing plumage color, long curving tail color, back tail color and shank color $(p<0.05)$. These results implied that the phenotypic of WTYC in this area had characteristics with standard perfection but not exhaustive.

\section{ACKNOWLEDGEMENTS}

This research was funded by Pibulsongkram Rajabhat University, Thailand for its kind support. Authors would like to thank the participating White Tailed-Yellow Chicken farmers and the staff of the Provincial Livestock Office of the Department of Livestock Development in Mueang District, Phitsanulok Province, Thailand, for providing the data in this research.

\section{REFERENCES}

Abinawanto A, Effendi PS. 2017. Biodiversity of the Gaga chicken from Pinrang, South Sulawesi, Indonesia based on the bioacoustic analysis and morphometric study. Biodiversitas 18: 1618-1623.

Akaravittayakun V. 1991. Fighting Cock production. Community agriculture book project, Bangkok, Thailand. [Thailand]

Alabi OJ, Norris D, Egena SSA. 2012. Comparative Study of Three Indigenous Breeds of South Africa: Body Weight \& Linear Body Measurements. Agric J 3: 220-225.

Amnueysit P, Amnueysit K, Toumsakul S. 2000a. Diversity of Thai Cocks at Amphur Muang Pichit Province 1) Breeds of Cocks. In: $38^{\text {th }}$ Kasetsart University Annual Conference, 1-4 February 2000. [Thailand]

Amnueysit P, Amnueysit K, Toumsakul S, Potikoung B. 2000b. Diversity of Thai Cocks at Amphur Muang Pichit Province 2) Luang Group. In: Proc. $38^{\text {th }}$ Kasetsart University Annual Conference, 1-4 February 2000. [Thailand]

Apuno AA, Mbap ST, Ibrahim T. 2011. Characterization of local chickens (Gallus gallus domesticus) in Shelleng and Song Local Government Areas of Adamawa State, Nigeria. Agric Bio J North America 2: 614.

Tancho A. 1995. Poultry Production. Oden store, Bangkok, Thailand. [Thailand]

Biodiversity Research section. 2012. Naresuan Fighting Cock. www.breeding.dld.go.th/biodiversity/chm/pvp_chm/provineculture/N aresuan\%20Fighting\%20Cock.htm. [Thailand]

Buranawit K, Chailungka C, Wongsunsri C, Laenoi W. 2016. Phenotypic characterization of Thai native black-bone chickens indigenous to northern Thailand. Thai J Vet Med 46: 547-554.

Buvanendran V, Merritt ES. 2011. Correlated responses in egg quality traits to selection for early body weight in meat type chicken. Can J Genet Cytol 14: 477-482.

Chaiyachet O, Prakobsaeng N, Pondee N. 2016. Phenotypic Characterization and Identification of Thai Native Chickens in Maha Sarakham Province. Prawarun Agri J 13: 155-165. [Thailand]

Choprakarn K. 2000. Native Chicken and Hybrid Native Chicken: Past and Present. Ubon Ratchathani University, Ubon Ratchathani. [Thailand]

Choprakarn K, Wongpichet K. 2007. Village chicken production systems in Thailand. Poultry in the 21st 14 Century. FAO, Bangkok. www.fao.org/ag/againfo/home/events/bangkok2007/docs/part3/3_5.p df

Daikwo IS, Okpe AA, Ocheja JO. 2011. Phenotypic Characterization of Local Chickens in Dekina. Int J Poult Sci 10: 444-447. 
Duangjinda M, Choprakarn K, Suwanlee S, Amnueysit P, Thieme O. 2012. Impact of the avian influenza outbreak on indigenous chicken genetic resources in Thailand. World's Poultry Science 68: 503512.

FAO. 2012. Phenotypic characterization of animal genetic resources. FAO Animal Production and Health Guidelines No. 11. Rome. Italy.

Gueye EF, Ndiaye A, Branckaert RDS. 1998. Prediction of body weight on the basis of body measurements in mature indigenous chickens in Senegal. Livest Res Rural Devel $10 \quad$ (3). www.lrrd.org/lrrd10/3/sene103.htm

Guni FS, Katule AM. 2013. Characterization of local chickens in selected districts of the Southern Highlands of Tanzania: I. Qualitative characters. Livest Res Rural Devel 25 (9). www.lrrd.org/lrrd25/9/guni25153.htm

Haq A., Akram M, Mukhtar N, Rehman S and Ramzan M. 2003. Effect of Parental Comb Size and Body Weight on Subsequent Performance in Lyallpur Silver Black Layers. Pakistan J Life Soc Sci 1 (2): 98-101.

Kanta J, Sapphung S, Yodket N, Siangthip P, Amyai S, Lailak C, Rattanapradit P, Yaemkong S. 2018. Diversity of Local Wisdom in Leuang Hang Kao Chicken Raising of Small Scale Farmers in Phitsanulok Province. J Agri Res Ext 35: 887-894. [Thailand]

Kumpala K, Kuha K, Termsombatthaworn P, Nasinporn N. 2016. Study on morphology of Thai native chickens of ethnic groups in Nan province. Khon Kaen Agr J 44: 377-381. [Thailand]

Laenoi W, Kunkalw W, Buranawit K. 2015. Phenotypic characterization and farm management of indigenous chicken reared in highland region of northern Thailand. Agric Agric Sci Procedia 5: 127-132.

Maw AA, Kawabe K, Shimogiri T, Rerkamnuaychoke W, Kawamoto Y, Masuda S, Okamoto S. 2015. Genetic Diversity and Population Structure in Native Chicken Populations from Myanmar, Thailand, and Laos by Using 102 Indels Markers. Asian-Australas J Anim Sci 28: 14-19.

Mekchay S, Supakankul P, Assawamakin A, Wilantho A, Chareanchim W, Tongsima S. 2014. Population structure of four Thai indigenous chicken breeds. BMC Genetics 15: 1-9.

Phitsanulok Provincial Livestock Office. 2005. Naresuan Fighting Cock: Animal in Phitsanulok. Phitsanulok, Thailand. [Thailand]

Rachsumpao B. 2004. A Study on Genetic Characteristics Distribution of Thai Native Chicken (Gallus domesticus) in Sakhon Nakhon Province. Full research report, Rajamangala University of Technology Isan. Nakhon Ratchasima, Thailand. [Thailand]

Rattanawaraha A. 1998. Science and Art: Fighting Cock production Matichon Printing, Bangkok, Thailand. [Thailand]

Sarker NR, Hoque A, Faruque S, Islam N, Bhuiyan FH. 2014. An ex-situ study on body characteristics and effect of plumage color on body weight of indigenous chicken (Gallus domesticus) in Bangladesh. Animal Sci J 36: 79-84.
SAS. 2004. SAS 9.13 Help and documentation. SAS Institute Inc., Cary, NC, USA.

Shahjahan M, Amin MR. Bhuiyan AKFH. 2011. Diversity in performance of indigenous chicken in some selected areas of Bangladesh in-situ. In: Proceedings of 9th Asia Pacific Poultry Conference, the World's Poultry Science Association Taiwan Branch, Taipei, Taiwan, 20-23 March 2011.

Singh MK, Nayak GD, Sardar KK. 2016. Phenotypic characterization of native chicken populations reared under family-based free-range scavenging system in Odisha, India. Indian J Anim Res 50: 839-845.

Soipeth U, Chirarat N, Chalermsan N, Yeamkong S, Rattanapradit P, Laorodphan N, Jaipong P, Charoensook R, Numthuam S, Incharoen T, Singkum N, Yoysakul A. 2017. Diversity of Thai Indigenous Leuang Hang Kao Chicken follows standard perfection in Phitsanulok Province. Khon Kaen Agric J 45: 684-689.

Faruque S, Siddiquee NU, Afroz MA, Islam MS. 2010. Phenotypic characterization of Native Chicken reared under intensive management system. J Bangladesh Agric Univ 8: 79-82.

Tabassum F, Hoque MA, Islam F, Ritchil CH, Faruque MO, Bhuiyan AKFH. 2014. Phenotypic and morphometric characterization of indigenous chickens at Jhenaigati upazila of Sherpur district in Bangladesh. SAARC J Agric 12: 154-169.

Tanchau A. 1995. Poultry production. Odeon Store, Bangkok, Thailand. [Thailand]

Thai Meteorological Department. 2014. The weather in Thailand. https://www.tmd.go.th/en/

Thinh NH, Tuan HA, Dang PK, Doan BH. 2015. Multi-spurred chicken breed and livelihood of ethnic People in North Vietnam: characterisation and prospects. Khon Kaen Agr J 43: 25-30.

Tungtakanpoung N. 2015. Phitsanulok Province Naresuan Fighting Cock. Dtra goon Thai Printing Ltd., Phitsanulok, Thailand. [Thailand]

Yaemkong S. 2014. Diversity of phenotypic characteristics of Thai Indigenous Chicken in Phitsanulok Province. Rajabhat J Sci Humanit Soc Sci 15: 63-73. [Thailand]

Yaemkong S, Rattanapradit P, Nguyen Ngoc T, Charoensuk R, Chirarat N, Soipethand U, Sirikanda Yaemkong. 2017. Diversity of Traditional Knowledge and Local Wisdom of Indigenous Chickens Farmers in Bang Krathum, Nakhon Thai, Mueang and Chat Trakan Districts Phitsanulok Province. J Appl Ani Sci 10: 39-46.

Yaemkong S, Tuan NN. 2016. Phenotypic Characterization of Native Chicken Ecotypes in Lower Northern, Thailand. In: The 17th AsianAustralasian Association of Animal Production Societies Animal Science Congress. Fukuoka, Japan, 22-25 August 2016. 